\title{
Applied Undergraduate English Teaching based on the Analytic Hierarchy Process
}

\author{
Xin Yuan ${ }^{1, a^{*}}$ \\ ${ }^{1}$ School of Foreign Studies, Suzhou University, Suzhou, Anhui 234000, China \\ a617316841@qq.com
}

\begin{abstract}
Keywords: Curriculum implementation; English classroom; Analytic Hierarchy Process Development Evaluation; Teaching Evaluation.
\end{abstract}

\begin{abstract}
This paper attempts to establish a teacher evaluation object, student evaluation of College English teaching quality evaluation system, details the steps analytic hierarchy process, gives the right of each index indicator system for scientific and objective evaluation of English classroom teaching quality to provide a theoretical basis and practical framework. In this paper, AHP calculated the weight of each index evaluation system in college English teaching weight, as an example describes a method of solving problems. In establishing English teaching evaluation, taking into account factors is relatively simple, but in general outlines the various factors that influence college English classroom teaching, but in practical applications first need to design a scientific, complete and operable strong, from the all-round, multi-angle indicator system to reflect the English classroom teaching. Analytic Hierarchy Process must be in an appropriate set of evaluation system based on the ability to make a global assessment of the object, the integrity of the system evaluation.
\end{abstract}

\section{Introduction}

English is for all university offer basic courses on strengthening students' quality of education, expanding knowledge, cultivating talent plays a very important role [1-3]. So, how effective English teaching, directly affect the quality of personnel training, so the English classroom teaching evaluation, teaching quality assessment to establish the applicable system, as English teaching must face [4]. In general, the teaching evaluation involving teachers, students and teaching management in three areas, in the past focused on the development of measures to grasp the quality of teaching and teacher education management from the perspective of the subject from the teaching activities not pay enough attention on the evaluation of students, and students directly involved in teaching the whole process of teachers teaching ideas, feelings teaching attitude, teaching methods and teaching effectiveness deepest, most say, therefore, in the background to the reform of college English as a carrier network and multimedia teaching mode, explore student classroom teaching evaluation body has important practical significance [5, 6]. The rapid development of the network so that people can be very easy to get a lot of information from around the world, the network speed up exchanges and international cooperation at the same time changing the lifestyle and values of the people [7]. Human subjectivity increasingly highlight the multicultural society has gradually become the mainstream of cultural forms. Universities train highly qualified personnel as the main place, it must be made more comprehensive and detailed requirements for the training of personnel [8,9]. Expand the development of curriculum implementation process evaluation studies of the ultimate goal to is to promote the comprehensive development, evaluation studies courses advocated "development" concept is emphasized that the implementation of development programs of teachers and students in the process. Development of curriculum evaluation is to emphasize the human personality is formed and body development, not only of contemporary society and to promote the "harmony and development" of the times to meet the bulk phase, but also for the value orientation of curriculum evaluation study pointed out the direction [10]. Analytic Hierarchy Process is the overall objective of the decision problem by layers sub-goals, evaluation criteria until the order specific equipment investment program is divided into different hierarchies, and then starting to solve the judgment 
feature vector matrix approach, each level is obtained each element of the priority level of an element on a heavy, final approach coupled with the right and hierarchical merging of the overall objective of the final weight of each alternative plan, the final weight of the largest person is the optimal solution. Priorities is a relative measure of the so-called here, it shows the various alternative solutions in a characteristic evaluation criteria or sub-target, relative standard measure under the superior level, and each sub-goal target in terms of importance to the floor a relative measure of the degree. Analytic Hierarchy Process is more suitable to have a layered staggered evaluation of the target system, and target and difficult to quantitatively describe the decision problem. Its use is to construct judgment matrix, find the maximum

\section{Analytic Hierarchy Process used in English Teaching Evaluation}

Analytic Hierarchy Process. Analytic Hierarchy Process (AHP) is a 1970s by the US operations research professor proposed is simple, flexible and practical multi-criteria decision making methods. It down depending on the nature of the problem and to achieve the desired composition factors the problem, according to the relationship between the factors factor hierarchy, forming a hierarchy model, and then analyzed by layer and, ultimately, the lowest level of the most important factors for weight value. This method of quantitative and qualitative analysis combined comparison to determine the final comprehensive weight to subjective judgment and deal with the number of forms of expression, the result is often more objective and accurate. In summary, the quality evaluation of college English teaching, few available objective indicators describe and analyze, you can only use the most subjective indicators to describe, so we use the analytic hierarchy process to determine the specific weight of each indicator index system weight. We evaluated the quality of English teaching as the target layer, the three levels of the same influence and determine the factors that English teaching as a criterion layer, more specific indicators as an index layer. Based on the above analysis, we can construct a hierarchical structure model, shown in Fig. 1.

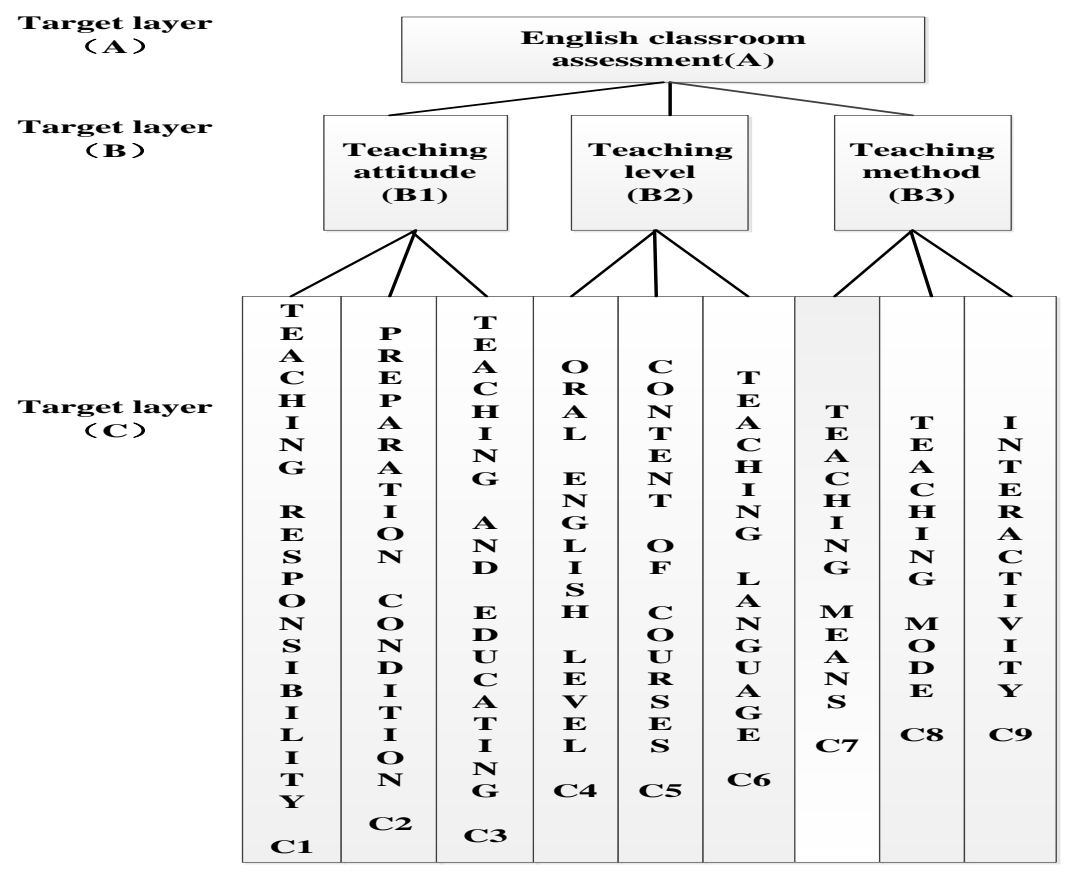

Figure 1. English teaching evaluation hierarchical structure model

Universities in China from the current university students' English learning outcomes criteria, our country is still passed the exam test scores as the main evaluation criteria. Thus, the students' English language practical application is weak, deaf learners for English Learners in College English course in no way a minority. Some comrades also pointed out: "Students of the practical application of language ability is poor; to change this situation, the university conducted a number of English reform, 
although the reform has achieved some success, but not ideal '5. Due to fierce international competition, talent, and English is the world's most widely used language, as a social pillar of arsenic flowing Students need to get rid of deaf English, English practical ability to obtain, I think this is the requirement of society is the era giving obligations. Comparative judgment matrix.After the establishment of hierarchical structure, then to invite experts to rule layer and index layer factors to judge and compare, judgment matrix. It should be noted that this paper is from the perspective of students on college English classroom teaching evaluation, which invited 10 pairs of college students scoring index system, where the proportion using 1-9 scale (meaning see Tab. 1), the qualitative and quantitative judgment, which constructed a number of comparison judgment matrix, as shown in Table 2 to 4.

Table 1. 1 9 Scale

\begin{tabular}{|c|c|}
\hline Scale & Meaning \\
\hline 1 & The two elements are equally important. \\
\hline 3 & $\begin{array}{l}\text { One of the two elements is slightly more important than the } \\
\text { other one. }\end{array}$ \\
\hline 5 & $\begin{array}{l}\text { One of the two elements is obviously more important than } \\
\text { the other one. }\end{array}$ \\
\hline 7 & $\begin{array}{l}\text { One of the two elements is strongly more important than the } \\
\text { other one. }\end{array}$ \\
\hline 9 & $\begin{array}{l}\text { One of the two elements is extremely more important than } \\
\text { the other one. }\end{array}$ \\
\hline $2,4,6,8$ & Intermediate value above the two adjacent scales \\
\hline Reciprocal value & $\begin{array}{l}\text { if }{ }^{a_{i j}} \text { represents element } i \text { compared with }{ }^{j},{ }^{1 / a_{i j}} \text { represents } \\
\text { element }{ }^{j} \text { compared with }{ }^{i}\end{array}$ \\
\hline
\end{tabular}

Developmental evaluation refers to the basis for the development of certain development goals and values, evaluators and evaluation objects together to develop mutually agreed development goals, the use of technology and the development of evaluation methods for quality development of teachers, job duties and job performance value judgments so that teachers in the development of education evaluation activities, and constantly self-understanding, self-development, self-improvement, continue to achieve different levels of development of 19 goals in the process. For this reason, we believe that the development of evaluation refers to the "people text" harmonious values as a guide, teacher in the English curriculum implementation process, the two sides in order to enhance the students' own English teaching literacy and English language proficiency, using a diversified way to communicate with each other, feedback information in a spiral manner so that both sides get promoted in the campaign and then the value of such a process for forming judgments.

Table 2. Index layer - criterion layer(B1) judgment matrix

\begin{tabular}{|c|c|c|c|c|}
\hline B1 & C1 & C2 & C3 & weight \\
\hline C1 & 1 & $1 / 2$ & $1 / 3$ & 0.1634 \\
\hline C2 & 2 & 1 & $1 / 2$ & 0.2970 \\
\hline C3 & 3 & 2 & 1 & 0.5396 \\
\hline
\end{tabular}

Consistency check: $\lambda_{\max } \mid=3.0092 \quad$ C.I. $=0.0046 \quad$ C.R. $=0.0079<0.1$ 
Table 3. Index layer - criterion layer(B2) judgment matrix

\begin{tabular}{|c|c|c|c|c|}
\hline B2 & C4 & C5 & C6 & weight \\
\hline C4 & 1 & $1 / 2$ & 2 & 0.2970 \\
\hline C5 & 2 & 1 & 3 & 0.5396 \\
\hline C6 & $1 / 2$ & $1 / 3$ & 1 & 0.1634 \\
\hline
\end{tabular}

Consistency check: $\lambda_{\max } \mid=3.0092 \quad$ C.I. $=0.0046 \quad$ C.R. $=0.0079<0.1$

Table 4. Index layer - criterion layer(B3) judgment matrix

\begin{tabular}{|c|c|c|c|c|}
\hline B3 & C7 & C8 & C9 & weight \\
\hline C7 & 1 & $1 / 3$ & $1 / 4$ & 0.1220 \\
\hline C8 & 3 & 1 & $1 / 2$ & 0.3196 \\
\hline C9 & 4 & 2 & 1 & 0.5584 \\
\hline
\end{tabular}

Consistency check: $\lambda_{\max } \mid=3.0183 \quad$ C.I. $=0.0091 \quad$ C.R. $=0.0158<0.1$

\section{The Total Level of Sorting and Overall Consistency Test}

The level of a single sort, calculate the criteria layer (B) with respect to the right to rule layer heavy target layer (A) ordering vector and index layer with respect to the index layer relative to the total level sorting target layer can be calculated by the formula, and the result as shown in Tab. 5 below. The total level of ordering random consistency ratio, sorted by the total level of consistency test, all judges have overall consistency.

Table 5. Total ordering result of evaluation of College English Classroom Teaching AHP model

\begin{tabular}{|c|c|c|c|c|}
\hline & $\begin{array}{c}\text { B1(Teaching } \\
\text { attitude) }\end{array}$ & $\begin{array}{c}\text { B2(Teaching } \\
\text { level) }\end{array}$ & $\begin{array}{c}\text { B3(Teaching } \\
\text { method) }\end{array}$ & \multirow{2}{*}{$\begin{array}{c}\text { Synthetic } \\
\text { weight }\end{array}$} \\
\cline { 2 - 4 } & 0.1220 & 0.3196 & 0.5584 & 0.0199 \\
\hline C1 & 0.1634 & & & 0.0362 \\
\hline C2 & 0.2970 & & & 0.0659 \\
\hline C3 & 0.5396 & & & 0.0949 \\
\hline C4 & & 0.2970 & & 0.1725 \\
\hline C5 & & 0.5396 & & 0.0522 \\
\hline C6 & & 0.1634 & & 0.0681 \\
\hline C7 & & & 0.1220 & 0.1785 \\
\hline C8 & & & 0.3196 & 0.3118 \\
\hline C9 & & & 0.5581 & \\
\hline
\end{tabular}

As can be seen from the index heavy weight in Tab. 5, the students that "teaching method" has an absolute importance in English classroom teaching evaluation system, which is consistent with the results of the objective facts, because a high level of English people do not $\mathrm{He}$ is an excellent English teacher, only to master the correct teaching methods in order to impart knowledge to students, so that students can effectively grasp the variety of knowledge, skills. In the "teaching method" of two indicators, the importance of "interactivity," the sub-index accounted for first, visible in student opinion, interaction between teachers and students occupy a very important position.

This is because the college English teaching is not only to disseminate information, more literal learning, training of language skills, so teachers should be based on the specific circumstances of the classroom, in a timely manner with summarized and concise language induction, summary or questions, teachers and students to discuss other ways to active classroom atmosphere, mobilize the enthusiasm of students, so that students' interest in learning more lasting. Meanwhile, in vision, 
hearing, said the curriculum can be used scene dialogue, language exercises in the form of panel discussions and performances clips, enhanced between teachers and students, interaction between students, which will practice language learning and use the language of an organic combination integrally.

\section{Conclusions}

In this paper, AHP calculated the weight of each index evaluation system in college English teaching weight, as an example describes a method of solving problems. In establishing English teaching evaluation, taking into account factors is relatively simple, but in general outlines the various factors that influence college English classroom teaching, but in practical applications first need to design a scientific, complete and operable strong, from the all-round, multi-angle indicator system to reflect the English classroom teaching. Analytic Hierarchy Process must be in an appropriate set of evaluation system based on the ability to make a global assessment of the object, the integrity of the system evaluation.

\section{References}

[1] Saaty T L, Vargas L G. Models, methods, concepts \& applications of the analytic hierarchy process[M]. Springer Science \& Business Media, 2012.

[2] Ergu D, Kou G, Peng Y, et al. The analytic hierarchy process: task scheduling and resource allocation in cloud computing environment[J]. The Journal of Supercomputing, 2013, 64(3): 835-848.

[3] Govindan K, Kaliyan M, Kannan D, et al. Barriers analysis for green supply chain management implementation in Indian industries using analytic hierarchy process[J]. International Journal of Production Economics, 2014, 147: 555-568.

[4] Ahmad S, Tahar R M. Selection of renewable energy sources for sustainable development of electricity generation system using analytic hierarchy process: A case of Malaysia[J]. Renewable energy, 2014, 63: 458-466.

[5] Lanjewar P B, Rao R V, Kale A V. Assessment of alternative fuels for transportation using a hybrid graph theory and analytic hierarchy process method[J]. Fuel, 2015, 154: 9-16.

[6] Herrmann A K, Huber F, Schellhase R. Using the Analytic Hierarchy Process and the Supermatrix Analysis to Determine the Relative Importance of Service Attributes[C]/Proceedings of the 1999 Academy of Marketing Science (AMS) Annual Conference. Springer International Publishing, 2015: 314-319.

[7] Papadopoulos A, Sioen I, Cubadda F, et al. TDS Exposure project: Application of the Analytic Hierarchy Process for the prioritization of substances to be analyzed in a Total Diet Study[J]. Food and Chemical Toxicology, 2015, 76: 46-53.

[8] Anis A, Islam R. The application of analytic hierarchy process in higher-learning institutions: a literature review[J]. 2015.

[9] Grošelj P, Stirn L Z, Ayrilmis N, et al. Comparison of some aggregation techniques using group analytic hierarchy process[J]. Expert Systems with Applications, 2015, 42(4): 2198-2204.

[10]Goossens A J M, Basten R J I. Exploring maintenance policy selection using the Analytic Hierarchy Process; an application for naval ships[J]. Reliability Engineering \& System Safety, 2015, 142: 31-41. 